\title{
USE OF INTERNET RESOURCES AND IT TOOLS AND CHARACTERISTICS OF HIGHER EDUCATION INSTITUTIONS IN SERBIA
}

The purpose of this paper is to determine whether there is a statistically significant influence of characteristics of higher education institutions and scientific fields in which their study programs are accredited, on use of Internet resources and IT tools. The term 'use of Internet resources and IT tools' here refers to enhancing students' skills in use of internet resources, services and technologies on Internet, thus enabling them to create and place new content, services and technologies on the internet.

This paper is based on data collected from 196 higher education institutions from Serbia, by a survey questionnaire. The research described in the paper was conducted in 2014. Data processing included a descriptive and correlative analysis. Based on this research, it can be concluded that there is a statistically significant influence of characteristics of higher education institutions on use of Internet resources and IT tools. Detailed research of the content of courses in higher education institutions that deal with internet and technologies surpasses the scope of this research and can be included in future research. This paper presents a new approach in research of influence of higher education institutions and their scientific fields' characteristics on use of Internet resources and IT tools in higher education. The results of this research can be used to improve educational strategies aiming to incorporate the internet use into the curricula of study programs in higher education institutions.

Keywords: higher education, internet, scientific fields, statistically significant influence, Serbia

1 Đorđe Petrović, PhD student, University of Niš, Faculty of Electronic Engineering, Serbia, petrovicdj@gmail.com 


\section{Introduction}

It is clear that the internet has become very important part of the learning process, scientific research, publishing results, etc. Apart from that, internet technologies enable independent access to information and help overcoming different limitations, such as geographic restrictions or restrictions that people with special needs might have.

The first reason for conducting this research was to explore students' competence and their ability to actively use the internet. In their paper, Fang Hua and Li Mei said that it is necessary to develop autonomous learning ability in students. ${ }^{1}$ For economics courses, Agarwal Rajshree and Day A. Edward explained two principles of internet resources use: firstly, these resources offer a tool of interaction that complements classroom instructions and facilitates learning; secondly, they create the opportunity for students to learn and use internet technology and yield positive externalities for future academic and career paths. ${ }^{2}$ It is our opinion that these two principles can be applied not only in economics courses, but all courses in general. This is especially important for second principle, regarding the future professional and academic careers of graduate students. When asked what their "primary area of internet interest" was, $15 \%$ of the participants in the survey identified themselves as research scientists and $11 \%$ as authors, editors or journalists. ${ }^{3}$ Based on everything above-mentioned, we feel that it is important that all students, as future experts and scientist, regardless of their study program, need to be highly skilled for active internet use. This was one of the reasons for our research - to gain insight into how much is the use of internet technologies present in higher education institutions.

The second reason for the research was to improve educational strategies in higher education institutions. According to the research "The future impact of the Internet on higher education", it is estimated that by 2020 universities will have moved towards the "life-long learning" model by expanding their online courses and creating hybrid learning spaces. Apart from that, Kirkwood Adrian and Price Linda explained that Technology Enhances Learning has two aims: changes in the means through which university teaching is conducted and changes in how university teachers teach and students learn. ${ }^{5}$ It can be seen from

Fang Hua, Li Mei, (2014): "Research and Practice on Experimental Teaching of 3D Innovation and Technology Series Courses", International Conference on Education Reform and Modern Management (ERMM).

2 Agarwal Rajshree, Day A. Edward, (1998): „The Impact of the Internet on Economic Education", The Journal of Economic Education, Volume 29, Issue 2.

3 Anderson Janna, Boyles Jan Lauren, Rainie Lee (2012): “The future impact of the Internet on higher education", Pew Research Center's Internet \& American Life Project.

$4 \quad$ Ibid

$5 \quad$ Kirkwood Adrian, Price Linda (2014): "Technology-enhanced learning and teaching in higher education: what is 'enhanced' and how do we know? A critical literature review.", Learning, Media and Technology, 39(1) pp. 6-36. 
this that the internet plays an important role in the teaching process, as well as in improving the quality of education and creating educational strategies.

The influence of internet on teaching and learning processes in higher education was the subject of a large number of studies and researches. In his study Baer S. Walter researched the role of internet in higher education. ${ }^{6}$ Also, the influence of internet on the manner and efficiency of students' learning was the subject of a large number of studies and researches (Youssef Adel Ben and Dahmani Mounir ${ }^{7}$, Dabbagh $\mathrm{Nada}^{8}$ ) as well as influence of internet on the way teaching is done (Valtonen Teemu et.al. $\left.{ }^{9}\right)$. Furthermore, there is a large number of case studies that deal with this subject, such as Makridou-Bousiou Despina ${ }^{10}$, Clothey Rebecca ${ }^{11}$, Arokiasamy Anantha Raj A and Nagappan Krishnaveni ${ }^{12}$, Bhumiratana Sakarindr and Commins Terry ${ }^{13}$, Glusac Dragana et.al..$^{14}$ As can be seen from the above-listed sources, there is a large number of studies and researches that deal with influence of internet on higher education. However, none of them deals with the influence of higher education institution and scientific fields characteristics on use of Internet resources and IT tools, which is the subject of our research.

$6 \quad$ Baer Walter S., (1998): “Will the Internet Transform Higher Education?", The Emerging Internet, Annual Review of the Institute for Information Studies.

$7 \quad$ Youssef Adel Ben, Dahmani Mounir, (2008): “The Impact of ICT on Student Performance in Higher Education: Direct Effects, Indirect Effects and Organizational Change, In: The Economics of E-learning" [online monograph], Revista de Universidad y Sociedad del Conocimiento (RUSC), Vol. 5, no. 1. UOC. <http://www.uoc.edu/rusc/5/1/dt/eng/ benyoussef_dahmani.pdf>

8 Dabbagh Nada, Kitsantas Anastasia, (2012): "Personal Learning Environments, social media, and self-regulated learning: A natural formula for connecting formal and informal learning", Internet and Higher Education, Volume 15, Issue 1, 3-8

9 Valtonen Teemu, Kukkonen Jari, Kontkanen Sini, Sormunen Kari, Dillon Patrick, Sointu Erkko, (2015): “The impact of authentic learning experiences with ICT on pre-service teachers' intentions to use ICT for teaching and learning”, Computers \& Education 81, 49-58 Makridou-Bousiou Despina, (2006): “The Effectiveness of Technology in Teaching High School Economics”, Journal of Information Technology Impact, Vol. 6, No. 1, 9-18.

11 Clothey Rebecca, (2010): "Current Trends in Higher Education: Expanding access in Asia Pacific through technology”, Comparative \& International Higher Education 2.

12 Arokiasamy Anantha Raj A, Nagappan Krishnaveni, (2012): "An analysis of globalization and higher education in Malaysia", Business Intelligence Journal, Vol.5 No.1 141-150.

13 Bhumiratana Sakarindr, Commins Terry, (2012): "Challenges and Opportunities for Higher Education in Asia in the Era of Globalization: Case of Thailand", Asian Journal on Education and Learning, 3(2), 21-27

14 Glusac Dragana, Makitan Vesna, Karuovic Dijana, Radosav Dragica, Milanov Dušanka, (2015): "Adolescents' informal computer usage and their expectations of ICT in teaching: Case study: Serbia”, Computers \& Education, 81 133-142 


\section{Research}

\subsection{Research goals and hypothesis}

This research aims at offering the answer to the question whether there is a connection between use of Internet resources and IT tools in higher education institutions and certain characteristics of those institutions and study programs they are accredited for.

The research hypothesis is:

- H1: Characteristics of higher education institutions have a statistically significant influence on use of Internet resources and IT tools in those institutions;

- H2: Some scientific fields of higher education institutions in which their study programs are accredited have statistically significant influence on use of Internet resources and IT tools in those institutions.

\subsection{Method}

This research includes 196 accredited higher education institutions in Serbia, that is, all institutions that were accredited by Commission for Accreditation and Quality Control in 2014. Higher education in Serbia is realized through academic and applied (professional, vocational) studies, based on the approved, i.e. accredited, study programs of higher education..$^{15}$ In academic studies, academic study programs are realized, enabling students to use the knowledge and skills necessary for inclusion into the working process. In applied studies, study programs are realized, enabling students to use the knowledge and skills necessary for inclusion into the working process.

Gathering data was done via the internet, by reviewing official web sites of all higher education institutions in Serbia. Standard 13, of Rules and regulations of accreditation standards and procedures for higher education institutions and their study program $\mathrm{s}^{16}$ that were adopted by National Council for Higher Education of the Republic of Serbia, relates to transparency of higher education institutions in Serbia. According to that standard, it is necessary that higher education institutions publish complete, precise, clear and available information, including a description of study programs and courses they are offering. In accordance with that, the internet research of official web sites of faculties and colleges in

15 Commission for Accreditation and Quality Control [Online], Available at: http:// www. kapk.org [Accessed: Oct., 2014.]

16 Rules and regulations of accreditation standards and procedures for higher education institutions and their study programs, (2006). Official Herald of RoS 106/2006, 112/2008, Available at: http://www.kapk.org/images/stories/pravilnici/2-Standards_of_accrd.pdf 
Serbia was conducted in 2014, with the goal to find the courses that deals with use of Internet resources and IT tools.

The questionnaire was filled for each of these 196 higher education institutions. The first part of the questionnaire consists of questions about characteristics of higher education institution, such as ownership, institution type and type of studies for which the institution is accredited. The second part of the questionnaire looks at scientific field in which the higher education institution accredited its study programs. These scientific fields include:

- Social and human sciences;

- Interdisciplinary, multidisciplinary and trans-disciplinary sciences;

- Medical sciences;

- Natural-mathematical sciences;

- Technical-technological science;

- Art

The third part of the questionnaire is about the courses that include internet technologies. In order to find and sort them more easily, the courses that deal with internet technologies are divided in two groups:

- Group 1: courses that deal with student training by using existing resources, services and technologies on the internet. Some of the typical courses we placed in "Group 1" are: IT Sciences, Internet Technology, Electronic Business, Internet Marketing, Internet Services, Information Systems, Basics of IT Sciences and similar.

- Group 2: courses that deal with student training by creating and publishing new content, services and technologies on the internet. Some of the typical courses we placed in "Group 2" are: Web Technology, Web Design, Web Programming, Web Mapping, Internet Programming, Internet Technology, Geographic Information Systems, Programming Internet Applications and similar.

In cases where the curricula are not adequately published on a higher education institution's web site, it can be concluded that the internet usage is at a very low level. Such faculties and colleges are marked in the questionnaire as not containing the courses that involve use of the internet.

The lists of questions from the questionnaire and short remarks (that will be used later in this document) are presented in Table 1. 
Table 1 Questions

\begin{tabular}{|c|l|}
\hline $\begin{array}{c}\text { Short } \\
\text { name }\end{array}$ & Questions \\
\hline Q11 & Is a higher education institution owned by state or privately owned? \\
\hline Q12 & Is a higher education institution faculty or college? \\
\hline Q13 & What type of college is it - of academic or applied studies? \\
\hline Q21 & $\begin{array}{l}\text { Does a higher education institution have accredited study programs in the } \\
\text { scientific field of social-human sciences? }\end{array}$ \\
\hline Q22 & $\begin{array}{l}\text { Does a higher education institution have accredited study programs in the } \\
\text { scientific field of interdisciplinary, multidisciplinary and trans-disciplinary } \\
\text { sciences? }\end{array}$ \\
\hline Q23 & $\begin{array}{l}\text { Does a higher education institution have accredited study programs in the } \\
\text { scientific field of medical science? }\end{array}$ \\
\hline Q24 & $\begin{array}{l}\text { Does a higher education institution have accredited study programs in the } \\
\text { scientific field of natural and mathematic science? }\end{array}$ \\
\hline Q25 & $\begin{array}{l}\text { Does a higher education institution have accredited study programs in the } \\
\text { scientific field of technical-technological science? }\end{array}$ \\
\hline Q26 & $\begin{array}{l}\text { Does a higher education institution have accredited study programs in the } \\
\text { scientific field of art? }\end{array}$ \\
\hline Q31 & $\begin{array}{l}\text { Are there any courses at a higher education institution that include training } \\
\text { students for using existing resources, services and technologies? }\end{array}$ \\
\hline Q32 & $\begin{array}{l}\text { Are there any courses at a higher education institution that include training } \\
\text { students to create and publish new content, services and technologies on the } \\
\text { internet? }\end{array}$ \\
\hline
\end{tabular}

\subsection{Results}

The analysis is presented in two parts: descriptive and correlational. Data processing consists of descriptive method and correlative statistics that enable a rational description of the computer usage and expectations dealt with in this research. Testing correlative analysis was used for hypothesis in order to reveal the direction and level of the relation of the variables: usage and expectation.

Data received from questionnaire for 196 accredited higher education institutions in Serbia are analyzed. First step in statistical deduction consists of descriptive statistics, which is presented in Table 2. This table contains short name of questions, the number of answered questions in the questionnaire, minimum, maximum, mean and standard deviation.

The results of the correlation analysis are also presented in Table 3, where Pearson correlation was used. Statistically significant correlations are bolded and marked as ${ }^{*} \mathrm{p}<0.05$ and ${ }^{* *} \mathrm{p}<0.01$. 
Table 2 Descriptive Statistics

\begin{tabular}{|c|c|c|c|c|c|}
\hline Dimensions & N & Minimum & Maximum & Mean & Std. Deviation \\
\hline Q11 & 196 & 1 & 2 & 1.22 & 0.418 \\
\hline Q12 & 196 & 1 & 2 & 1.34 & 0.474 \\
\hline Q13 & 196 & 1 & 2 & 1.31 & 0.462 \\
\hline Q21 & 196 & 1 & 2 & 1.56 & 0.498 \\
\hline Q22 & 196 & 1 & 2 & 1.04 & 0.198 \\
\hline Q23 & 196 & 1 & 2 & 1.08 & 0.275 \\
\hline Q24 & 196 & 1 & 2 & 1.11 & 0.316 \\
\hline Q25 & 196 & 1 & 2 & 1.34 & 0.476 \\
\hline Q26 & 196 & 1 & 2 & 1.10 & 0.303 \\
\hline Q31 & 196 & 1 & 2 & 1.54 & 0.500 \\
\hline & 196 & 1 & 2 & 1.17 & 0.380 \\
\hline
\end{tabular}

Table 3 Correlations

\begin{tabular}{|c|c|c|c|}
\hline & & Q31 & Q32 \\
\hline Q11 & $\begin{array}{c}\text { Pearson Correlation } \\
\text { Sig. (2-tailed) } \\
\mathrm{N}\end{array}$ & $\begin{array}{c}-\mathbf{0 . 2 3 5 * *} \\
0.001 \\
196 \\
\end{array}$ & $\begin{array}{c}-0.117 \\
0.102 \\
196 \\
\end{array}$ \\
\hline Q12 & $\begin{array}{c}\text { Pearson Correlation } \\
\text { Sig. (2-tailed) } \\
\mathrm{N}\end{array}$ & $\begin{array}{c}\mathbf{0 . 3 3 9}^{* *} \\
0.000 \\
196 \\
\end{array}$ & $\begin{array}{c}0.130 \\
0.070 \\
196 \\
\end{array}$ \\
\hline Q13 & $\begin{array}{c}\text { Pearson Correlation } \\
\text { Sig. (2-tailed) } \\
\text { N }\end{array}$ & $\begin{array}{c}\mathbf{0 . 3 0 8}^{* *} \\
0.000 \\
196\end{array}$ & $\begin{array}{c}\mathbf{0 . 1 6 3 ^ { * }} \\
0.022 \\
196\end{array}$ \\
\hline Q21 & $\begin{array}{c}\text { Pearson Correlation } \\
\text { Sig. (2-tailed) } \\
\text { N }\end{array}$ & $\begin{array}{c}-0.049 \\
0.493 \\
196\end{array}$ & $\begin{array}{c}-0.160^{*} \\
0.025 \\
196\end{array}$ \\
\hline Q22 & $\begin{array}{c}\text { Pearson Correlation } \\
\text { Sig. (2-tailed) } \\
\mathrm{N}\end{array}$ & $\begin{array}{c}0.037 \\
0.607 \\
196\end{array}$ & $\begin{array}{c}0.042 \\
0.562 \\
196\end{array}$ \\
\hline Q23 & $\begin{array}{c}\text { Pearson Correlation } \\
\text { Sig. (2-tailed) } \\
\text { N }\end{array}$ & $\begin{array}{c}0.016 \\
0.824 \\
196\end{array}$ & $\begin{array}{c}0.011 \\
0.878 \\
196\end{array}$ \\
\hline Q24 & $\begin{array}{c}\text { Pearson Correlation } \\
\text { Sig. (2-tailed) } \\
\mathrm{N}\end{array}$ & $\begin{array}{c}0.072 \\
0.318 \\
196\end{array}$ & $\begin{array}{c}0.136 \\
0.058 \\
196\end{array}$ \\
\hline Q25 & $\begin{array}{c}\text { Pearson Correlation } \\
\text { Sig. (2-tailed) } \\
\mathrm{N}\end{array}$ & $\begin{array}{c}0.132 \\
0.066 \\
196 \\
\end{array}$ & $\begin{array}{c}\mathbf{0 . 2 3 8}^{* *} \\
0.001 \\
196 \\
\end{array}$ \\
\hline Q26 & $\begin{array}{c}\text { Pearson Correlation } \\
\text { Sig. (2-tailed) } \\
\text { N }\end{array}$ & $\begin{array}{c}-0.159^{*} \\
0.026 \\
196\end{array}$ & $\begin{array}{c}-0.065 \\
0.362 \\
196\end{array}$ \\
\hline
\end{tabular}




\section{Discussion}

Insight in the percentage of the internet studies in higher education institutions in Serbia is achieved by gathering data in a previously described manner. $56 \%$ of total number of faculties and $22 \%$ of total number of colleges do not have courses that deal with use of Internet resources and IT tools in their study programs. So, compared to a total number of accredited faculties and colleges, courses that deal with use of Internet resources and IT tools there are at colleges in much higher percentage (78\%) than at faculties (44\%).

Table 3 shows that there is a statistically significant correlation between question groups Q11, Q12 and Q13 with question Q31, and there is also a statistically significant correlation between questions Q13 with question Q32. That means the following:

- There is a statistically significant influence of characteristics of higher education institutions on use of Internet resources, services and technologies in those institutions. More precisely, compared with total number, there topics are studied considerably more at state than in private higher educational institutions, and much more at colleges than in faculties and also much more at applied studies than in academic studies.

- There is a statistically significant influence of type of studies on the training of students to create and publish new content, services and technologies in the internet. Specifically, compared with total number, there topics are studied much more at applied studies than in academic studies.

Based on the above - mentioned, it can be concluded that initial hypothesis $\mathrm{H} 1$ is verified, that is, there is a statistically significant influence of characteristics of higher education institutions on use of Internet resources and IT tools in those institutions.

Table 3 also shows that there is a statistically significant correlation between questions Q26 with question Q31, and also between Q21 and Q25 with question Q32. That means the following:

- Compared with total number, in a much lesser extent, use of Internet resources, services and technologies is done in higher education institutions that have accredited study programs in scientific field of art;

- Compared with total number, in a much lesser extent, training of students to create and publish new content, services and technologies on the internet is done in higher educational institutions that have accredited study programs in scientific field of social and human science;

- Compared with total number, in a much larger extent, training of students to create and publish new content, services and technologies on the internet is done in higher educational institutions that have accredited study programs in scientific field of technical-technological studies; 
- Compared with total number, for scientific field of interdisciplinary, multidisciplinary and trans-disciplinary sciences and medical science, it was not proven that there is statistically significant correlation with use of Internet resources and IT tools.

Based on the above-said it can be concluded that initial hypothesis $\mathrm{H} 2$ is verified, that is, there is a statistically significant influence of some scientific fields of accredited study programs on higher education institutions for use of Internet resources and IT tools, in those institutions.

\section{Conclusion}

This research was completed by searching the official websites of faculties and colleges in Serbia and data were gathered through such available sources. If a faculty or a college did not adequately publish their study programs and curricula on the internet, it can be concluded that use of Internet resources and IT tools at those institutions is not at a satisfactory level or non-existent. On the other hand, there are specialized faculties and colleges in which there are entire study programs solely devoted to use of Internet resources and IT tools and in accordance with that there is a much higher number of courses dedicated to use and creation of content and services for the Internet. Detailed research of courses that deal with internet and technologies surpasses the scope of this research and can be included in future research.

Based on the results of the research, we can conclude that there is a statistically significant influence of characteristics of higher education institutions and scientific fields in which study programs of those institutions are accredited, on use of Internet resources and IT tools as a part of teaching and learning processes. We feel that these results provide the basis for improvement of educational strategies aiming at incorporating use of Internet into the courses within the study programs of higher education institutions. 


\section{References}

- Agarwal Rajshree, Day A. Edward, (1998): „The Impact of the Internet on Economic Education", The Journal of Economic Education, Volume 29, Issue 2.

- Anderson Janna, Boyles Jan Lauren, Rainie Lee, (2012): “The future impact of the Internet on higher education”, Pew Research Center's Internet \& American Life Project.

- Arokiasamy Anantha Raj A, Nagappan Krishnaveni, (2012): "An analysis of globalization and higher education in Malaysia", Business Intelligence Journal, Vol.5 No.1 141-150.

- Baer Walter S., (1998): “Will the Internet Transform Higher Education?”, The Emerging Internet, Annual Review of the Institute for Information Studies.

- Bhumiratana Sakarindr, Commins Terry, (2012): “Challenges and Opportunities for Higher Education in Asia in the Era of Globalization: Case of Thailand", Asian Journal on Education and Learning, 3(2), 21-27

- Clothey Rebecca, (2010): "Current Trends in Higher Education: Expanding access in Asia Pacific through technology", Comparative \& International Higher Education 2.

- Commission for Accreditation and Quality Control [Online], Available at: http:// www.kapk.org [Accessed: Oct., 2014.]

- Dabbagh Nada, Kitsantas Anastasia, (2012): "Personal Learning Environments, social media, and self-regulated learning: A natural formula for connecting formal and informal learning", Internet and Higher Education, Volume 15, Issue 1, 3-8

- Fang Hua, Li Mei, (2014): "Research and Practice on Experimental Teaching of 3D Innovation and Technology Series Courses", International Conference on Education Reform and Modern Management (ERMM).

- Glusac Dragana, Makitan Vesna, Karuovic Dijana, Radosav Dragica, Milanov Dušanka, (2015): “Adolescents' informal computer usage and their expectations of ICT in teachinge: Case study: Serbia", Computers \& Education, 81 133-142

- Kirkwood Adrian, Price Linda (2014): “Technology-enhanced learning and teaching in higher education: what is 'enhanced' and how do we know? A critical literature review." Learning, Media and Technology, 39(1) pp. 6-36.

- Makridou-Bousiou Despina, (2006): “The Effectiveness of Technology in Teaching High School Economics”, Journal of Information Technology Impact, Vol. 6, No. 1, 9-18. 
- Rules and regulations of accreditation standards and procedures for higher education institutions and their study programs, (2006). Official Herald of RoS 106/2006, 112/2008, Available at: http://www.kapk.org/ images/stories/pravilnici/2-Standards_of_accrd.pdf

- Valtonen Teemu, Kukkonen Jari, Kontkanen Sini, Sormunen Kari, Dillon Patrick, Sointu Erkko, (2015): “The impact of authentic learning experiences with ICT on pre-service teachers' intentions to use ICT for teaching and learning", Computers \& Education 81, 49-58

- Youssef Adel Ben, Dahmani Mounir, (2008): “The Impact of ICT on Student Performance in Higher Education: Direct Effects, Indirect Effects and Organisational Change, In: The Economics of E-learning" [online monograph], Revista de Universidad y Sociedad del Conocimiento (RUSC), Vol. 5, no. 1. UOC. http://www.uoc.edu/rusc/5/1/dt/ eng/benyoussef_dahmani.pdf 


\section{UPOTREBA RESURSA NA INTERNETU I IT ALATA I KARAKTERISTIKE VISOKOŠKOLSKIH INSTITUCIJA U SRBIJI}

Cilj ovog istraživanja je da se utvrdi da li postoji statistički značajan uticaj karakteristika visokoškolskih ustanova i naučnih polja u kojima su akreditovani studijski programi u tim ustanovama, na upotrebu resursa na Internetu i IT alata. Izraz "upotreba resursa na Internetu i IT alata" se ovde prvenstveno odnosi na usavršavanje studenata u korišćenju resursa, servisa i tehnologija na Internetu, a zatim i na usavršavanje studenata za izradu i postavljanje novih sadržaja, usluga i tehnologija na Internet.

Ovaj dokument se zasniva na podacima o 196 visokoškolskih institucija iz Srbije, koji su prikupljeni uz upotrebu anketnog upitnika. Istraživanje koje je ovde opisano je sprovedeno tokom 2014. godine. Obrada prikupljenih podataka obuhvata deskriptivnu i korelacionu analizu. Na osnovu ovog istraživanja, može se zaključiti da postoji statistički značajan uticaj karakteristika visokoškolskih institucija na korišćenje resursa na Internetu i IT alata. Detaljno istraživanje sadržaja predmeta u visokoškolskim institucijama koji se bave Internetom prevazilazi opseg ovog istraživanja i može da bude obrađeno u nekom sledećem istraživanju. Ovaj rad predstavlja novi pristup u istraživanju uticaja karakteristika visokoškolskih institucija i njihovih naučnih oblasti na korišćenje resursa na Internetu i IT alata u visokom obrazovanju. Rezultati ovog istraživanja se mogu koristiti za poboljšanje obrazovnih strategija koje se tiču integracije upotrebe Interneta u nastavne planove studijskih programa visokoškolskih institucija.

Ključne reči: visoko obrazovanje, naučna polja, statistički značajan uticaj, Srbija 